УАK 342:35

ББК 67.401 .02

DOI 10.22394/1682-2358-2019-1-53-58

V.I. Sharyn, Doctor of Sciences (Economics), Professor of the Labor Economy and Personnel Management Department, Ural State Economic University

\section{POSSIBLE NEGATIVE CONSEQUENCES OF RAISING THE RETIREMENT AGE OF RUSSIAN OFFICIALS}

Possible negative consequences of raising the retirement age in the civil and municipal service are studied. The author substantiates the need for regulatory legal support of the peculiarities of service in old age, the introduction of special technologies of employment associated with a decrease in the duration and intensity of loads.

Key words and word-combinations: civil service, municipal service, raising the retirement age.
В.И. Шарин, доктор экономических наук, профессор кафедрь экономики труда и упраљления персоналом Уральского государственного экономического университета (email: Sharin_vi@usue.ru)

\section{ВОЗМОЖКНЫЕ НЕГАТИВНЫЕ ПОСАЕАСТВИЯ \\ ПОВЫШЕНИЯ ПЕНСИОННОГО ВОЗРАСТА РОССИЙСКИХ ЧИНОВНИКОВ}

\begin{abstract}
Аннотация. Исследуются возможные негативные последствия повышения пенсионного возраста на государственной гражданской службе и муниципальной службе. Обоснована необходимость нормативного правового обеспечения особенностей прохождения службы в пожилом возрасте, внедрение специальных технологий занятости, связанных со снижением продолжительности и интенсивности нагрузок.

Ключевые слова и словосочетания: государственная гражданская служба, муниципальная служба, повышение пенсионного возраста.
\end{abstract}<smiles>[18OH]</smiles>
25 ampess 2016 г. № 36-Ф3 «О внесении изменений в отдельные законодательные акты Российской Федерации в части увеличения пен-

* Исследование выполнено при поддержке РФФИ в рамках научного проекта № 19-010-00545 «Прогноз вмияния повышения пенсионного возраста на рождаемость в России». 
сионного возраста отдельным категориям граждан» внесены изменения в Фелеральный закон от 15 декабря 2001 г. № 166-Ф3 «О государственном пенсионном обеспечении в Российской Федерации» в части увеличения возраста, по достижении которого назначается страховая пенсия по старости в периоА замещения государственных и муниципальных Аолжностей, Аолжностей государственной и муниципальной службы, а также в Федеральный закон от 28 декабря 2013 г. № 400-Ф3 «О страховых пенсиях» в части стажа государственной и муниципальной служббы мля назначения пенсии за выслугу мет.

В результате установлено поэтапное повышение пенсионного возраста государственных и муниципальных служащих: Аля мужчин - на 5 лет (65 лет), женщин - на 8 мет (63 года), путем ежкегодного увеличения на полгода, начиная с 2017 г. Кроме того, увеличивается на 5 мет (с 15 до 20 мет) минимальный стаж государственной и муниципальной службы, дающий право на назначение пенсии за выслугу мет и определение ее размера, также путем ежкегодного увеличения на полгода, начиная с 2017 г. Планируется, что действие данного Закона снизит бюджетные расходы более чем на 600 млрд рубмей уже в первый год его применения [1].

В результате повышения пенсионного возраста пожилые государственные служащие через несколько иет станут массовым явлением; межку тем на государственной и муниципальной службе так и не появицись соответствующие механизмы работы с Аанной категорией чиновников, учитывающие возрастные особенности.

Исследование возможных последствий повышения пенсионного возраста, а также предложение мер по обеспечению прохождения службы чиновников

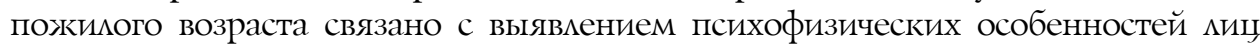
пожилого возраста, а также анализом факторов, снижающих риски влияния повышения пенсионного возраста на эффективность деятельности чиновников.

К мицам пожилого возраста, согласно классификации Европейского регионального бюро ВО3 (WHO), относятся женщины 55-74 лет, мужкчины 60-74 мет. С учетом повышения пенсионного возраста до 63 мет Аля жкенщин и 65 - Аля мужчин государственных и муниципамьных служащих в возрасте 55-63 мет (женщины) и 60-65 мет (мужчины) следует относить к категории пожицых.

Пожилым мюдям в возрасте 60-65 ^ет, как правило, сложно заниматься трудовой деятельностью, осваивать новые технологии, проблемы со здоровьем негативно сказываются не только на эффективности их работы, но и на Аеятельности органа вцасти, где они служат. Согласно статистике, у миџ старше шестидесяти мет наблюдается ухудшение памяти (Ао 75\%) [2], артериальная гипертензия регистрируется более чем у 50\% [3], им присущи замедмение работы большинства функциональных систем, наличие нескольких хронических заболеваний, а также внешние проявления старения. Старение - это снижение с возрастом упорядоченности структур организма и увеличение степени их износа, выражающееся в уменьшении жизнеспособности организма - в снижении функциональных возможностей и способностей к адаптации, а также в повышении вероятности заболеваний и смерти от размичных причин [4, с. 57]. 
Ао момента увеличения пенсионного возраста мишь немногие пожимые чиновники продолжали государственную гражданскую службу. Численность работников, замещающих государственные Аолжности и домжности гражАанской служббы пенсионного возраста (на 1 октября 2016 г.), по данным Федеральной службы государственной статистики, составила 7,3\% (мужчин $1,2 \%$, женщин - 6,1\%) от общей численности соответствующих работников, что отражкает жкизненные установки и состояние работоспособности вышеАших в отставку чиновников. Увецичение пенсионного возраста повлечет вынужденную занятость в пожилом возрасте, а это при возрастном ухудшении здоровья, снижении работоспособности и повышении интенсивности труда чаще всего ведет к росту хронических заболеваний, связанных с Алительными курсами мечения, а также к инвалидизации пожилых государственных служащих $[5$, c. 131$]$.

Нередко пожилые сотрудники становятся иниџиаторами конфликтов в трудовом комлективе, в этом возрасте характер мюдей несколько меняется, негативные черты перестают компенсироваться, их все сложнее скрывать от окружающих [6]. Профессиональный и жизненный опыт Аиџ преАпенсионного и раннего пенсионного возраста не всегда воспринимается как полезный, так как был получен в иных социальных условиях, а за счет неспособности таких работников трудиться в полную силу снижается эффективность работы всего подраздемения государственной службы [7] .

И.С. Шванова выявила четкую границу возраста 61-65 ^ет, после которой чиновники государственных органов и подведомственных структур начинают восприниматься скорее не как ценный трудовой ресурс, а как препятствие, тормозящее развитие организации и внедрение инноваций. При этом отношение к ним начинает меняться уже по достижении 56-60 кет, с которого, по мнению респондентов, начинается постепенная трансформация сотрудника в «бамласт» [8]. Снижение работоспособности пожимых чиновников на фоне постоянного роста интенсивности деятельности влияет на увецичение нагрузки на комлег, что несет риски роста психологического напряжения в комективе. В связи с этим увеличение пенсионного возраста потребует особого подхода к сохранению приемлемого уровня работоспособности государственных гражданских служащих, индивидуальных мотиваций к эффективному труау.

Кроме снижения эффективности деятельности чиновников пожилого возраста, увеличение пенсионного возраста повлияет на иные стороны жизнеАеятельности: замедлится АОАжностной рост молодых чиновников, вырастет «текучесть» кадров из-за отсутствия карьерных перспектив, увеличится напряженность отношений межАу поколениями в трудовом коммективе [9].

Повышение возраста выхода на пенсию приведет к увеличению периода прохождения карьерных ступеней и повысит конкуренџию за замещение Аолжностей. Жемающие самореализоваться женщины, а таких большинство, сегодня планируют прежде всего карьерный рост, поэтому нередко откладывают деторождение. Проџессы, связанные с пенсионными изменениями, усугубят данную тенденџию и могут повлиять на снижение рожАаемости. Кроме 
того, планирующие рождение ребенка женщины ранее могли рассчитывать на помощь родителей, выходящих на пенсию в 55 мет, что важно при дефиџи-

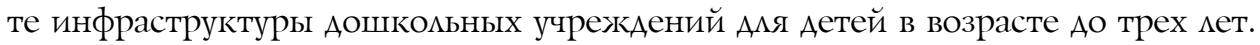
Аоступность неформального ухода за ребенком, обеспечиваемого бабушками и дедушками, увеличивает шансы рождения первого ребенка и имеет значение дия принятия решения о рождении последующих детей [10, с. 149].

Таким образом, повышение пенсионного возраста российских чиновников будет иметь несколько большие последствия, чем возрастное снижкение их работоспособности и эффективности труда, так как окажет вцияние на рост инвалидизаџии пожилых госслужащих, профессиональные предпочтения мо-

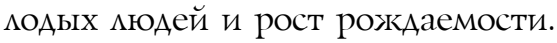

Зарубежная практика использования труда пожилых работников имеет многолетнюю историю [11-13] и потребовама создания соответствующей нормативно-правовой базы, регламентирующей трудовые отношения дмя конкретных

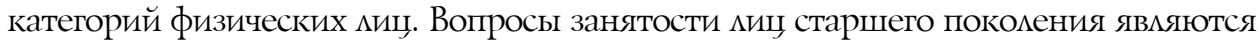
предметом регулирования международных организаций. Общие советы работодателям по улучшению условий труда пожкилых работников в производственной сфере сформулированы в п. 13 Рекомендаций Межлународной организацией труда № 162 «О пожилых трудящихся», утвержденной 23 июня 1980 г. Так, работодателям рекомендуется следующее: изменять формы организации труда, если они ведут к чрезмерному напряжению пожилых работников; приспосабливать рабочее место и задания к возможностям трудящегося пенсионера, используя все имеющиеся технические среАства, в частности, принщипы эргономики, чтобы сохранить здоровье и работоспособность и предупредить несчастные случаи; организовывать систематический контроль состояния здоровья пожилых работников; обеспечивать безопасность и гигиену труда пенсионеров [14].

У работников пожилого возраста не отмечается резкого снижения квацификации, однако они, как правило, нуждаются в сокращении объема работ, в изменении производственного ритма. Не случайно при трудоустройстве пенсионеры отдают предпочтение тем видам трудовой деятельности, которые не требуют единого ритма и темпа работ, а наоборот, Аопускают индивидуальное моделирование режима труда и отдыха и выполнения рабочего задания по комичеству и качеству сообразно собственным возможностям. Условия труда, в частности режким рабочего времени и время отдыха, Аолжны соответствовать трудоспособности конкретного пожилого человека [15]. Поддержкка работающего старшего поколения, по мнению некоторых исследователей, например В.К. Потемкина, Аолжна вкцючать предоставление определенных иьгот: гибкого рабочего графика; неполного рабочего Аня; чрезвычайного отпуска; работы на Аому; совмещения должностей, работ; перерыва в карьере (временный уход с работы); временного перевода на Аругую Аолжность [16] .

Исследователями отмечается неравномерность старения мюдей, что обусцовцено множеством причин объективного и субъективного характера. Категория «пожилые государственные служащие» (55-65 мет), безусловно, усилит свою НеОАНОРОАНОсть, ПоэТОМУ ПотребуеТся ИНАИвИАУаАьНЫЙ ПоАХОА КаАРОвЫх службб к пожицым служащим исходя из их состояния работоспособности. 
В связи с естественным процессом старения служащих необходима регумярная диагностика «остаточной работоспособности» в цемях установмения дефектов их здоровья методом вычисления биологического возраста организма в целом и его отдельных систем, что даст возможность определения профимя старения и выбора на этой основе индивидуальной схемы профилактики старения в соответствии с индивидуальными характеристиками клиента. Это обеспечит возможность решать задачи сдерживания темпа старения, квалифицированного применения средств биостимуляџии, Алительного сохранения высокого уровня физической и психической активности [17, с. 9] Аля обеспечения эффективной деятельности пожилых чиновников и органов государственной вмасти.

Наиболее важным мотивом государственных и муниципальных служащих является карьерный рост и связанная с ним материальная стимумяџия чиновников. Аля служашего пожилого возраста этот мотив перестает действовать, поэтому арсенац мотиваџий будет ограничиваться нематериальными поощрениями. Пожилые государственные служащие потребуют особого внимания работодателя - государства, иначе издержкки от их занятости, учитывая возрастные особенности, превысят получаемую полезность и сделают их деятельность экономически и социально неэффективной. В системе управления персоналом к пожилым скужащим необходим комплексный подход - реализаџия совокупности мероприятий нормативного, организаџионного, методоцогического, исследовательского характера.

Увеличение пенсионного возраста чиновников, по нашему мнению, не имело достаточного изучения и обсуждения в профессиональных сообществах (медицине, психологии, экономике труда, управлении персоналом и Ар.), СМИ. Кроме экономического эффекта, полезность данной меры не очевидна. Увеличение количества мюдей старшего возраста на государственной службе потребует новых подходов к прохождению ими службы в части характера и условий труда, мотиваций, профессиональной подготовки и иных аспектов, а также потребует научных исследований, сопровождающих процесс трудовой занятости пожилых государственных и мунищипальных служащих.

Обеспечению эффективности использования трудовых ресурсов государственных и муниципальных служащих пожилого возраста, а также достижению баланса интересов государства как работодателя и работающих кищ старшего поколения, по нашему мнению, будут способствовать реализация комплекса определенных мер. Во-первых, необходимо формирование на государственном уровне политики прохождения государственной и муниџипальной службы мицами пожилого возраста. Во-вторых, требуется обеспечение нормативного, организаџионного и методологического регулирования деятельности кадровых служб по работе с пожкилыми чиновниками. В-третьих, целесообразно переориентирование кадровых службб государственных и муниципальных органов власти с каАрового делопроизводства на применение технологий управления персоналом, обеспечивающих мотивацию к прохождению службы в старшем возрасте и планирование профессионального развития. В-четвертых, уместно внедрение спещиальных технологий занятости, связанных со снижением про- 
Аолжительности и интенсивности нагрузок (включая неполный рабочий день, рабочую неделю, гибкий график работы, увеличенную продолжительность отпуска и др.). В-пятых, следует запланировать предоставление медиџинского обеспечения, соответствующего подАержанию работоспособности пожилых служащих, а также возможность досрочного выхода на пенсию по состоянию зАоровья.

\section{Библиографический список}

1. Дмитриева А.Я., Дубовик В.С. Литвиненко Г.Н. Проблема повышения пенсионного возраста в России. Ближайшее будущее // Современные научные исследования и разработки: материалы международной (заочной) научно-практической конференции / под общ. ред. А.И. Вострецова. Прага, 2017. URL: https://elibrary.ru/item.asp?id=28982136

2. Захаров $B$. Нарушение памяти и внимания в пожилом возрасте // Вестник эстетической медицины. 2009. Т. 8, № 1.

3. Горшунова Н.К., Терешина Е.В., Украинцева Д.Н. Артериальная гипертензия в пожилом возрасте: некоторые особенности патогенеза // Успехи геронтологии. 2010. Т. 23, № 4.

4. Славин В.Н., Крутько В.Н. Предмет, история и метод математической геронтологии // Труды Института системного анализа Российской академии наук. 2005. Т. 13. С. 57-65.

5. Римашевская H.M. Три предложения по совершенствованию демографической и семейной политики // Экономические и социальные перемены: факты, тенденции, прогноз. 2013. № 6 (30). С. 127-132.

6. Маликов А.Н., Смирнова Т.В. Профессиональные ресурсы в возрастной динамике // Поволжский торгово-экономический журнал. 2011. № 1.

7. Шаховой В.А. Формирование кадрового потенциала государственной службы // Управление мегаполисом. 2010. № 1.

8. Шванова И., Шебураков И. Управление карьерным развитием государственных служащих старшей возрастной группы // Интерактивная наука. 2016. № 5.

9. Шарин В.И., Ефремова Т.В. Необходимость новых подходов в работе кадровых служб в связи с увеличением пенсионного возраста государственных и муниципальных служащих // e-FORUM: интернет-журнал. 2018. № 1 (2) (янв. - март). URL: https://www.eforum-journal.ru

10. Бальбо Н., Биллари Ф.К., Миллс М. Рождаемость в развитых странах: обзор исследований // Демографическое обозрение. 2017. Т. 4, № 2. С. 133-195.

11. Breeze E., Fletcher A.E., Leon D.A. [et al.]. Do socioeconomic disadvantages persist into old age? Self-reported morbidity in a 29-year follow-up of the Whitehall Study // American Journal of Public Health. 2001. Vol. 91, № 2. P. 277-283.

12. Buckley N.J., Denton F.T., Robb A.L. [et al.]. Healthy aging at older ages: Are income and education important? // Canadian journal on aging-revue canadienne du vieillissement. 2004. Vol. 23, № 1. P. $155-169$.

13. Siegrist J., Wahrendorf M. Participation in socially productive activities and quality of life in early old age: findings from SHARE // Journal of European Social Policy. 2009. Vol. 19, № 4. P. 317-326.

14. Бурлака Н.П. Проблемы организации занятости лиц пенсионного возраста // Актуальные проблемы гуманитарных и естественных наук. 2016. № 5-2.

15. Щанина E.В. Пожилой человек в современном обществе // Университетское образование: сборник статей IX Междунар. науч.-метод. конф. Пенза, 2005.

16. Потемкин В.К. Управление персоналом: учебник для вузов. СПб., 2009.

17. Крутько В.И. Системный анализ и информатика здоровья и долголетия // Труды Института системного анализа Российской академии наук. 2005. Т. 13. С. 9-24. 